\title{
PEMANFAATAN LIMBAH BATU MARMER SEBAGAI PENGGANTI AGREGAT KASAR PADA CAMPURAN ASPAL BETON TERHADAP KARAKTERISTIK MARSHALL
}

\section{The Implementation Of Stone Marble Waste For Changer The Aggregate Rough To Mix Aplhalt Concrete Characteristics Of Marshal}

\author{
Andi Syaiful Amal ${ }^{1} \&$ Chairil Saleh ${ }^{2}$ \\ 1,2 Jurusan Teknik Sipil - Fakultas Teknik Univ. Muhammadiyah Malang \\ Alamat Korespondensi : Jl. Raya Tlogomas No. 246 Malang 65144 \\ Email : andiama199@yahoo.co.id
}

\begin{abstract}
The waste of marble stone is waste produced when manufactured processing of unused marble. The utilization of marble for road ossification material is one way to alleviate that waste of marble stone. The purpose of this research is finding out the advantage of marble stone waste as replacement of crude aggregate partly toward marshall characteristic on mixture of the concrete asphalt layer (Laston). Laston mixture with marble stone waste as replacement of crude aggregate used variation of $5 \%, 10 \%, 15 \%, 20 \%, 25 \%, 30 \%$ and $35 \%$. The result is ascertainable that using of marble stone waste is able to increase the marshall characteristic. The best laston mixture is produced content optimum of marble stone waste 17,5\%, The laston mixture produced : marshall stability $1050 \mathrm{~kg}$, marshall quotient 2,5 KN/mm, volume air void 4,5\% and film thickness $8,8 \mathrm{~mm}$.
\end{abstract}

Keyword : Laston Mixture, Marble Stone Waste, Marshall Characteristic

\begin{abstract}
Abstrak
Limbah batu marmer merupakan limbah yang dihasilkan pada saat proses pengolahan batu marmer yang tidak dimanfaatkan. Pemanfaatan limbah batu marmer untuk material perkerasan jalan adalah salah satu cara untuk mengurangi limbah batu marmer tersebut. Penelitian ini bertujuan untuk mengetahui manfaat limbah batu marmer sebagai pengganti agregat kasar terhadap karakteristik marshall pada campuran laston. Campuran laston dengan limbah batu marmer sebagai pengganti agregat kasar menggunakan variasi 5\%, 10\%, 15\%, 20\%, 25\%, 30\%, dan 35\%. Hasil penelitian ini diketahui bahwa penggunaan limbah batu marmer dapat meningkatkan karakteristik Marshall. Campuran laston terbaik dengan limbah batu marmer sebagai pengganti agregat kasar dihasilkan kadar limbah batu marmer optimum 17,5\%, menghasilkan campuran laston : marshall stability $1050 \mathrm{~kg}$, marshall quotient 2,5 $\mathrm{KN} / \mathrm{mm}$, volume air void $4,5 \%$ dan film thickness $8,8 \mathrm{~mm}$.
\end{abstract}

Kata kunci: campuran laston, limbah batu marmer, karakteristik marshall.

\section{PENDAHULUAN}

Laston atau lapisan aspal beton merupakan campuran antara agregat dengan bahan pengikat (aspal) yang diproses secara panas, dihampar dan dipadatkan pada suhu tertentu. Material agregat kasar batu merupakan sumber daya alam yang semakin lama akan habis dan tidak dapat diperbarui. Oleh karena itu dibutuhkan alternatif bahan pengganti material agregat kasar yaitu menggunakan limbah batu marmer. Limbah batu marmer adalah sisa limbah yang dihasilkan pada saat proses pengolahan batu marmer yang tidak dimanfaatkan. Perlu dilakukan suatu upaya pemanfaatan limbah batu marmer menjadi sesuatu yang lebih bermanfaat, salah satunya digunakan sebagai bahan alternatif agregat kasar pada campuran laston. Tujuan penelitian ini adalah untuk mengetahui pengaruh pemanfaatan limbah batu marmer terhadap karakteristik Marshall pada campuran lapisan aspal beton (LASTON) sebagai pengganti sebagian agregat kasar dan untuk mengetahui proporsi limbah batu marmer (optimum) pada campuran laston dengan limbah batu marmer sebagai pengganti sebagian agregat kasar terbaik. Penelitian skala laboratorium campuran Laston yaitu dengan pengujian marshall Standart dan Marshall Immesion tanpa modifikasi dimana kadar aspal yang digunakan 
adalah $4,5 \% ; 5 \% ; 5,5 \% ; 6 \% ; 6,5 \% ; 7 \% ; 7,5 \%$ terhadap berat total agregat. Analisa Marshall yang telah dilakukan didapatkan nilai kadar aspal optimum sebesar 6,85\% untuk campuran Laston dengan agregat halus limbah pecahan marmer, sedangkan untuk campuran yang beragregat batu pecah sebesar 6,9\%. (Istikhomah 2005). Di Indonesia biasa menggunakan 2 jenis konstruksi perkerasan yaitu konstruksi perkerasan lentur (flexible pavement) dan perkerasan kaku (rigid pavement), Konstruksi perkerasan lentur yaitu perkerasan yang menggunakan aspal sebagai bahan pengikat. Lapisan-lapisannya bersifat memikul dan menyebarkan beban lalu lintas ke tanah dasar dan konstruksi perkerasan kaku yaitu perkerasan yang menggunakan semen PC (Portland cement) sebagai bahan pengikat. Plat beton dengan atau tanpa tulangan diletakan diatas tanah dasar dengan atau tanpa lapisan pondasi bawah, Sukirman (2003). Limbah batu marmer merupakan sisa limbah yang dihasilkan pada proses pengolahan batu marmer yang tidak dimanfaatkan. Tjangroe, dkk, (2006)

\section{METODO PENELITIAN}

Penelitian ini dilakukan di Laboratorium Jalan Raya, Teknik Sipil, Fakultas Teknik, Universitas Muhammadiyah Malang. Adapun tahapan penelitian yang dilakukan, dijelaskan pada gambar 1 .

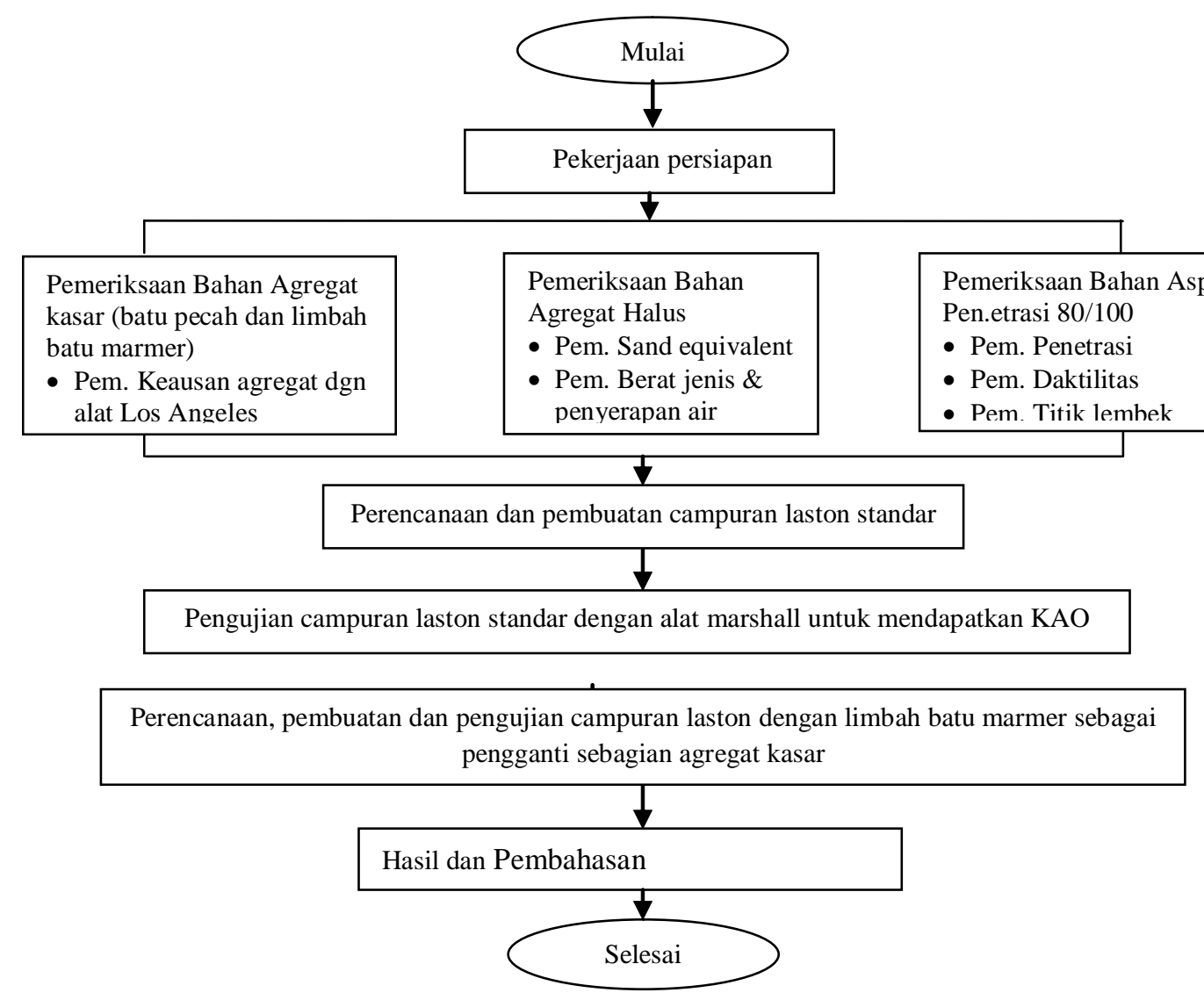

Gambar 1. Diagram Alur Tahapan Studi

Material yang digunakan antara lain sebagai berikut : (a) Kerikil (batu pecah) dan abu batu diperoleh dari pabrik pemecah batu Omah Campus, Kecamatan Dau, Kabupaten Malang; (b) Pasir alam diperoleh dari sungai Brantas Kelurahan Tlogomas, kecamatan Lowokwaru, Kota Malang; (c) Limbah batu marmer diperoleh dari Desa Besole, Kecamatan Campur Darat, Kabupaten Tulungagung; (d) Filler digunakan adalah Portland
Cement (PC) merek Semen Gresik; (e) Aspal digunakan adalah jenis aspal padat dengan penetrasi 80-100. Perencanaan campuran laston standar ditujukan untuk mendapatkan komposisi campuran, dengan langkah-langkah meliputi : pemilihan dan penentuan sifat agregat; penentuan campuran nominal; penentuan proporsi campuran; membuat benda uji. Pengujian campuran laston standar dengan alat Marshall (Marshall Test), ditujukan 
untuk mendapatkan nilai karakteristik Marshall. Hubungan antara kadar aspal dan nilai karakteristik marshall divisualisasikan dalam bentuk grafik, selanjutnya dihasilkankan kadar aspal optimum.

Campuran laston dengan limbah batu marmer menggantikan sebagian agregat kasar dibuat dengan kadar limbah batu marmer secara variatif: $5 \%, 10 \%$, $15 \%, 20 \%, 25 \%, 30 \%$, dan 35\%, (dibuat berdasarkan kadar aspal optimun campuran laston standar) . Pengujian campuran laston dengan limbah batu marmer sebagai pengganti sebagian agregat kasar menggunakan alat Marshall, diperoleh nilai karakteristik Marshall. Hubungan antara kadar limbah dan nilai karakteristik Marshall divisualisasikan dalam bentuk grafik, selanjutnya didapatkan kadar limbah batu marmer optimum dari campuran laston dengan limbah batu marmer sebagai pengganti agregat kasar.

\section{HASIL DAN PEMBAHASAN}

\section{Hasil Pemeriksaan Bahan}

Hasil pemeriksaan agregat kasar (batu pecah, limbah batu marmer) dan agregat halus (pasir alam, abu batu) disajikan pada tabel 1 dan tabel 2 . Berdasarkan analisa saringan agregat halus (grafik analisa saringan), diketahui perbandingan antara pasir alam : abu batu adalah $50 \%: 50 \%$. Kualitas aspal yang dijumlahkan penetrasi $80 / 100$ yang dijumlah: penetrasi $81,7 \times 0,1 \mathrm{~mm}$; titik lembek $49^{\circ} \mathrm{C}$; titik nyala $319^{\circ} \mathrm{C}$; titik bakar $320^{\circ} \mathrm{C}$; daktilitas $105 \mathrm{~cm}$ dan berat jenis $1,027 \mathrm{gr}$.

Tabel 1. Hasil Pemeriksaan Agregat Kasar

\begin{tabular}{|c|c|c|c|}
\hline Jenis Pemeriksaan & Syarat & Batu Pecah & $\begin{array}{c}\text { Limbah batu } \\
\text { marmer }\end{array}$ \\
\hline Keausan agregat kasar & $\operatorname{Max} 40 \%$ & $28,76 \%$ & $29,56 \%$ \\
\hline Berat jenis bulk (atas dasar kering oven) & $\operatorname{Min} 2,5 \mathrm{gr} / \mathrm{cm}^{3}$ & $2,59 \mathrm{gr} / \mathrm{cm}^{3}$ & $2,63 \mathrm{gr} / \mathrm{cm}^{3}$ \\
\hline Berat jenis bulk (atas dasar kering permukaan) & $\operatorname{Min} 2,5 \mathrm{gr} / \mathrm{cm}$ & $2,65 \mathrm{gr} / \mathrm{cm}^{3}$ & $2,65 \mathrm{gr} / \mathrm{cm}^{3}$ \\
\hline Berat jenis semu & $\operatorname{Min} 2,5 \mathrm{gr} / \mathrm{cm}^{3}$ & $2,77 \mathrm{gr} / \mathrm{cm}^{3}$ & $2,66 \mathrm{gr} / \mathrm{cm}^{3}$ \\
\hline Penyerapan air & $\operatorname{Max} 3 \%$ & $2,45 \%$ & $0,74 \%$ \\
\hline \multicolumn{4}{|l|}{ Analisa saringan } \\
\hline - Gradasi lolos 1/2", & $30 \%-100 \%$ & $43,28 \%$ & $61,54 \%$ \\
\hline - Gradasi lolos 3/8, & $0 \%-55 \%$ & $6,88 \%$ & $50,22 \%$ \\
\hline - Gradasi lolos no.4 & $0 \%-10 \%$ & $1,86 \%$ & $31 \%$ \\
\hline - Gradasi lolos no.8 & - & $1,40 \%$ & $19,18 \%$ \\
\hline - Gradasi lolos no.200 & $0 \%-1 \%$ & $0,52 \%$ & $0,75 \%$ \\
\hline
\end{tabular}

Tabel 2. Pemeriksaan Agregat Halus Pasir Alam Dan Abu Batu

\begin{tabular}{lllc}
\hline \multicolumn{1}{c}{ Jenis Pemeriksaan } & \multicolumn{1}{c}{ Syarat } & Pasir Alam & Abu Batu \\
\hline Nilai Sand Equivalent (SE) & Min 50\% & $98,78 \%$ & $86,97 \%$ \\
Berat jenis bulk (atas dasar kering oven) & Min 2.5gr/cm & $2,54 \mathrm{gr} / \mathrm{cm}^{3}$ & $2,47 \mathrm{gr} / \mathrm{cm}^{3}$ \\
Berat jenis bulk (atas dasar kering permukaan) & Min 2.5gr/cm & $2,56 \mathrm{gr} / \mathrm{cm}^{3}$ & $2,53 \mathrm{gr} / \mathrm{cm}^{3}$ \\
Berat jenis semu & Min2.5gr/cm & $2,60 \mathrm{gr} / \mathrm{cm}^{3}$ & $2,62 \mathrm{gr} / \mathrm{cm}^{3}$ \\
Penyerapan air & Max 3\% & $0,91 \%$ & $2,23 \%$ \\
Analisa saringan & & & \\
- Gradasi lolos no.8 & $95 \%-100 \%$ & $96,92 \%$ & $95,58 \%$ \\
- Gradasi lolos no.30 & $75 \%-100 \%$ & $77,05 \%$ & $75,71 \%$ \\
- Gradasi lolos no.200 & $0 \%-5 \%$ & $4,29 \%$ & $4,35 \%$ \\
\hline
\end{tabular}

\section{Campuran Laston Standar}

Campuran laston standar direncanakan dengan berdasar pada hasil pemeriksaan analisa saringan agregat kasar dan agregat halus (abu batu dan pasir alam), pemeriksaan berat jenis dan penyerapan agregat kasar dan agregat halus. Sifat-sifat agregat campuran laston standar disajikan pada tabel 3.

Tabel 3. Sifat-Sifat Agregat Campuran Laston Standar

\begin{tabular}{|c|c|c|c|c|c|c|}
\hline \multirow{2}{*}{$\begin{array}{c}\text { Agregat yang } \\
\text { tersedia }\end{array}$} & \multicolumn{2}{|c|}{ Gradasi lolos ayakan } & \multicolumn{3}{|c|}{ Berat jenis } & \multirow{2}{*}{$\begin{array}{l}\text { Absorbsi } \\
\text { air }(\%)\end{array}$} \\
\hline & $\# 8$ & $\# 200$ & Kering oven & SSD & Semu & \\
\hline batu pecah & 1,40 & 0,52 & 2,59 & 2,65 & 2,77 & 2,45 \\
\hline abu batu & 95,58 & 4,35 & 2,47 & 2,53 & 2,62 & 2,23 \\
\hline pasir alam & 96,92 & 4,29 & 2,54 & 2,56 & 2,60 & 0,91 \\
\hline
\end{tabular}


Penentuan rencana campuran berdasarkan asumsi kadar aspal 8,50\%, fraksi agregat kasar $45,00 \%$ dan fraksi bahan pengisi $6,80 \%$. Sedangkan fraksi agregat halus $39,70 \%$ menunjukkan penyesuaian terhadap fraksi agregat kasar, bahan pengisi dan kadar aspal agar volume total campuran $100 \%$. Dari hasil rumus matematika (metode matriks), didapat rancangan campuran nominal: batu pecah $44,01 \%$; abu batu $21,38 \%$; pasir alam $21,38 \%$; bahan pengisi 4,72\%; dan kadar aspal 8,5\%. Kadar aspal campuran nominal ditentukan dengan penyesuaian terhadap absorbsi air oleh agregat dengan rancangan campuran nominal, sehingga kadar aspal campuran nominal dipilih 6,9\%. Dengan demikian proporsi campuran nominal laston standar yang disesuaikan, disajikan pada tabel 4. Sedangkan proporsi campuran agregat laston standar disajikan pada tabel 5 .

Tabel 4. Penyesuaian Proporsi Campuran Nominal Laston Standar

\begin{tabular}{lcccccccc}
\hline & $\begin{array}{c}\text { Campuran } \\
\text { Mominal } \\
\text { MATERIAL }\end{array}$ & \multicolumn{7}{c}{ Campuran Nominal Disesuaikan (\%) } \\
& $\begin{array}{c}\text { Perhitungan } \\
(\%)\end{array}$ & 1 & 2 & 3 & 4 & 5 & 6 & 7 \\
\cline { 2 - 9 } & 44,01 & 44,01 & 44,01 & 44,01 & 44,01 & 44,01 & 44,01 & 44,01 \\
Batu Pecah & 21,38 & 22,93 & 22,68 & 22,43 & 22,18 & 21,93 & 21,68 & 21,43 \\
Abu Batu & 21,38 & 22,93 & 22,68 & 22,43 & 22,18 & 21,93 & 21,68 & 21,43 \\
Pasir Alam & 4,72 & 4,72 & 4,72 & 4,72 & 4,72 & 4,72 & 4,72 & 4,72 \\
BahanPengisi & 8,50 & 5,40 & 5,90 & 6,40 & 6,90 & 7,40 & 7,90 & 8,40 \\
Aspal (A) & 100 & 100 & 100 & 100 & 100 & 100 & 100 & 100 \\
TOTAL & & & & & & & & \\
\hline
\end{tabular}

Tabel 5. Proporsi Campuran Agregat Laston Standar

\begin{tabular}{lccccccc}
\hline \multicolumn{1}{c}{ Material } & & \multicolumn{7}{c}{ Proporsi Campuran Agregat (\%) } \\
& 1 & 2 & 3 & 4 & 5 & 6 & 7 \\
\hline Batu Pecah & 46,52 & 46,77 & 47,02 & 47,27 & 47,53 & 47,79 & 48,05 \\
Abu Batu & 24,24 & 24,10 & 23,97 & 23,83 & 23,68 & 23,54 & 23,40 \\
Pasir Alam & 24,24 & 24,10 & 23,97 & 23,83 & 23,68 & 23,54 & 23,40 \\
Bahan Pengisi & 4,99 & 5,02 & 5,05 & 5,07 & 5,10 & 5,13 & 5,16 \\
TOTAL & 100 & 100 & 100 & 100 & 100 & 100 & 100
\end{tabular}

Benda uji campuran laston standar dibuat berdasarkan perhitungan gradasi agregat campuran laston standar yang dihasilkan dari gradasi agregat kombinasi dan gradasi agregat (Tabel 6). Hasil pemeriksaan campuran laston standar dengan menggunakan alat Marshall disajikan pada tabel 7 . Berdasarkan gradasi agregat kombinasi campuran laston standar (tabel 6) dan hasil pemeriksaan campuran aspal dengan alat Marshall (Tabel 7), nilai rata-rata karakteristik marshall campuran laston standar disajikan pada tabel 8.

Hubungan kadar aspal dengan nilai karakteristik marshall campuran laston standar (Tabel 8) divisualisasikan dalam bentuk grafik pada gambar 2. Berdasarkan gambar 2, didapat kadar aspal optimum campuran laston standar $7 \%$, dengan kualitas campuran laston standar: marshall stability $799 \mathrm{~kg}$, marshall quotient $2 \mathrm{KN} / \mathrm{mm}$, volume air void $3.6 \%$ dan film thickness $9 \mathrm{~mm}$.

Tabel 6. Gradasi Agregat Kombinasi Dan Gradasi Agregat

\begin{tabular}{|c|c|c|c|c|c|c|c|c|c|c|c|c|}
\hline \multirow{2}{*}{$\begin{array}{c}\text { UKURAN } \\
\text { AYAKAN } \\
\text { ASTM }\end{array}$} & \multicolumn{4}{|c|}{ GRADASI AGREGAT } & \multicolumn{2}{|c|}{ GRADAS } & \multicolumn{2}{|c|}{ I AGREGAT } & \multicolumn{3}{|c|}{ KOMBINASI } & \multirow{2}{*}{$\begin{array}{l}\text { FAKT. } \\
\text { PERM. } \\
\text { AGRE. }\end{array}$} \\
\hline & A & B & $\mathrm{c}$ & $\mathrm{d}$ & I & II & III & IV & V & VI & VII & \\
\hline 1 " & 100 & 100 & 100 & 100 & 100 & 100 & 100 & 100 & 100 & 100 & 0 & \\
\hline $3 / 4$ “ & 1 & 10 & 10 & 100 & 100 & 100 & 100 & 100 & 100 & 100 & 100 & $1 \mathrm{x}$ \\
\hline $1 / 2 "$ & 43,28 & 100 & 100 & 100 & 73,61 & 73,47 & 73,33 & 73,19 & 73,04 & 72,89 & 72,75 & 0,41 \\
\hline $3 / 8$ “ & 6,88 & 100 & 100 & 100 & 56,68 & 56,45 & 56,21 & 55,98 & 55,74 & 55,50 & 55,26 & \\
\hline \# 4 & 1,86 & 100 & 100 & 100 & 54,34 & 54,10 & 53,85 & 53,60 & 53,35 & 53,10 & 52,85 & $\begin{array}{l}\mathrm{x} \quad 0,41 \\
\end{array}$ \\
\hline
\end{tabular}




\begin{tabular}{|c|c|c|c|c|c|c|c|c|c|c|c|c|}
\hline$\# 8$ & 1,40 & 95,58 & 96,92 & 100 & 52,31 & 52,07 & 51,84 & 51,60 & 51,36 & 51,12 & 50,87 & $\begin{array}{ll}\mathrm{x} & 0,82\end{array}$ \\
\hline \# 16 & 1,28 & 87,75 & 85,71 & 100 & 47,64 & 47,43 & 47,22 & 47,01 & 46,79 & 46,58 & 46,36 & 1,64 \\
\hline \# 30 & 1,10 & 75,71 & 77,05 & 100 & 42,54 & 42,36 & 42,17 & 41,99 & 41,80 & 41,62 & 41,43 & 2,87 \\
\hline \# 50 & 0,87 & 49,68 & 50,34 & 100 & 29,64 & 29,54 & 29,43 & 29,32 & 29,20 & 29,09 & 28,98 & 6,14 \\
\hline \# 100 & 0,71 & 21,08 & 25,50 & 100 & 16,62 & 16,58 & 16,54 & 16,51 & 16,47 & 16,43 & 16,40 & x 12,29 \\
\hline \# 200 & 0,52 & 4,35 & 4,29 & 100 & 7,33 & 7,35 & 7,36 & 7,38 & 7,39 & 7,41 & 7,43 & x 32,27 \\
\hline PER. & \multicolumn{4}{|c|}{ a. Agregat Kasar } & 46,52 & 46,77 & 47,02 & 47,27 & 47,53 & 47,79 & 48,05 & \\
\hline CAMP. & \multicolumn{4}{|c|}{ b. Abu Batu } & 24,24 & 24,10 & 23,97 & 23,83 & 23,68 & 23,54 & 23,40 & \\
\hline AGR.(\% & \multicolumn{4}{|c|}{ c. Pasir } & 24,24 & 24,10 & 23,97 & 23,83 & 23,68 & 23,54 & 23,40 & \\
\hline BERAT & \multicolumn{4}{|c|}{ d. Bahan Pengisi } & 4,99 & 5,02 & 5,05 & 5,07 & 5,10 & 5,13 & 5,16 & \\
\hline \multicolumn{13}{|l|}{ TOT.AGR. } \\
\hline LUAS TOT & Г. PERI & KAAN & GRE & $\mathrm{Kg})$ & 8,88 & 9,28 & 9,26 & 9,24 & 9,22 & 9,20 & 8,77 & \\
\hline
\end{tabular}

Tabel 7. Hasil Pemeriksaan Campuran Laston Standar Dengan Alat Marshall

\begin{tabular}{ccccccc}
\hline No. & \multicolumn{5}{c}{ Bacaan arloji Marshall Test } \\
\cline { 2 - 7 } Benda & \multicolumn{3}{c}{ Stabilitas } & \multicolumn{4}{c}{ Flow } \\
\cline { 2 - 7 } Uji & A & B & C & A & B & C \\
\hline 1. & 53 & 54 & 50 & 340 & 350 & 340 \\
2. & 51,9 & 49 & 47 & 450 & 380 & 370 \\
3. & 52,2 & 48 & 44 & 310 & 290 & 340 \\
4. & 33 & 31 & 40 & 410 & 420 & 480 \\
5. & 27,7 & 25,3 & 30 & 660 & 590 & 470 \\
6. & 33 & 31 & 27,7 & 410 & 420 & 660 \\
7. & 25,3 & 29 & 37 & 590 & 360 & 515 \\
\hline
\end{tabular}

Tabel 8. Nilai Rata-Rata Karakteristik Marshall Campuran Aspal Laston Standar

\begin{tabular}{ccccc}
\hline Kadar & Marshall & Maeshall & Film & $\begin{array}{c}\text { Vol. } \\
\text { Bitumen (\%) }\end{array}$ \\
& stability (kg) & Quitient(kn/mm) & thickness(mm) & Air Void(\%) \\
\hline $5,40 \%$ & 845,1 & 2,41 & 6,90 & 7,34 \\
$5,90 \%$ & 814 & 2,00 & 7,19 & 6,95 \\
$6,40 \%$ & 834,7 & 2,61 & 7,80 & 6,26 \\
$6,90 \%$ & 631,3 & 1,42 & 8,42 & 5,19 \\
$7,40 \%$ & 552,5 & 0,94 & 9,06 & 4,87 \\
$7,90 \%$ & 673,56 & 1,33 & 9,70 & 3,96 \\
$8,40 \%$ & 678,28 & 1,36 & 10,83 & 3,28 \\
& & & & \\
\hline
\end{tabular}

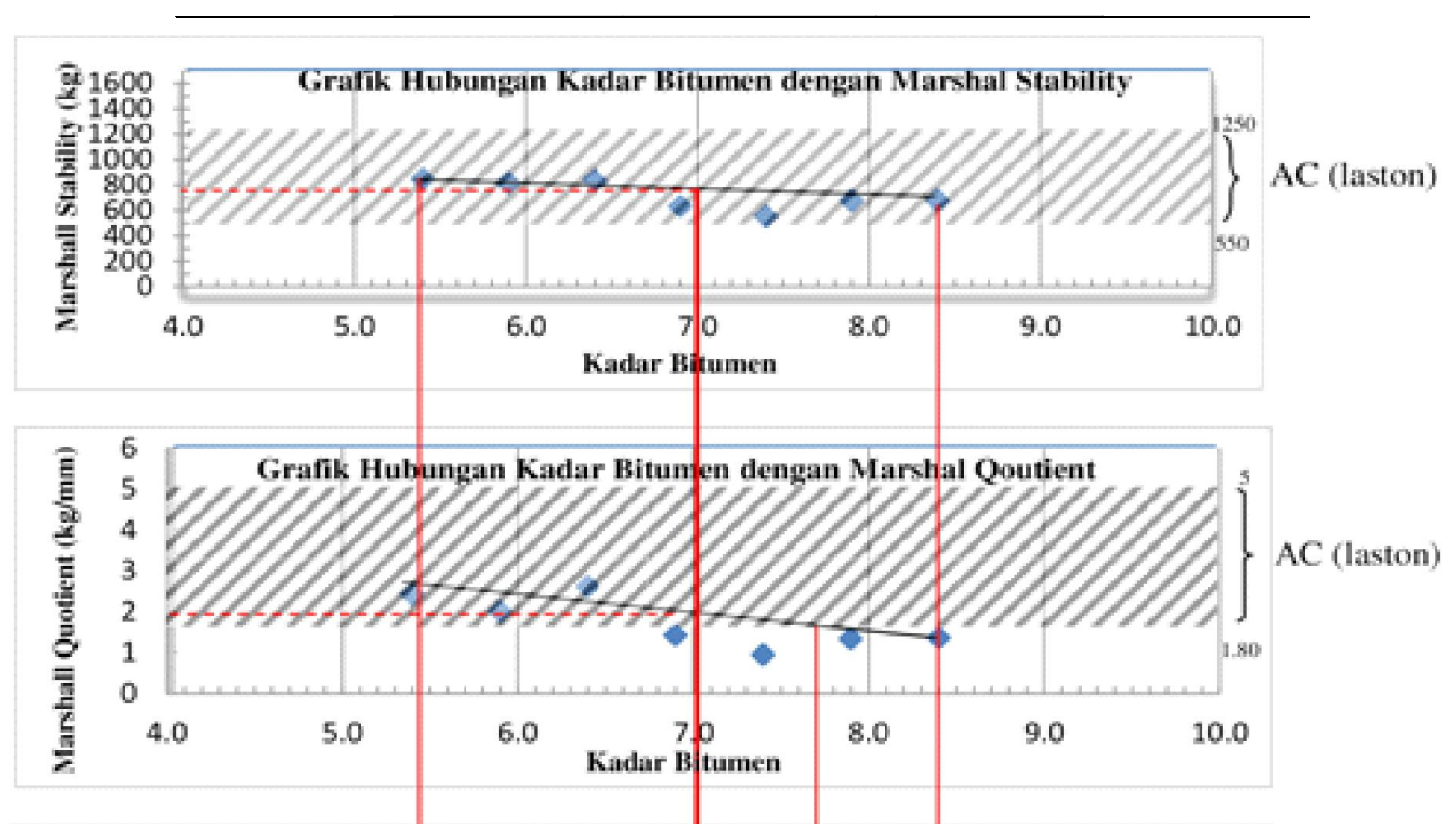




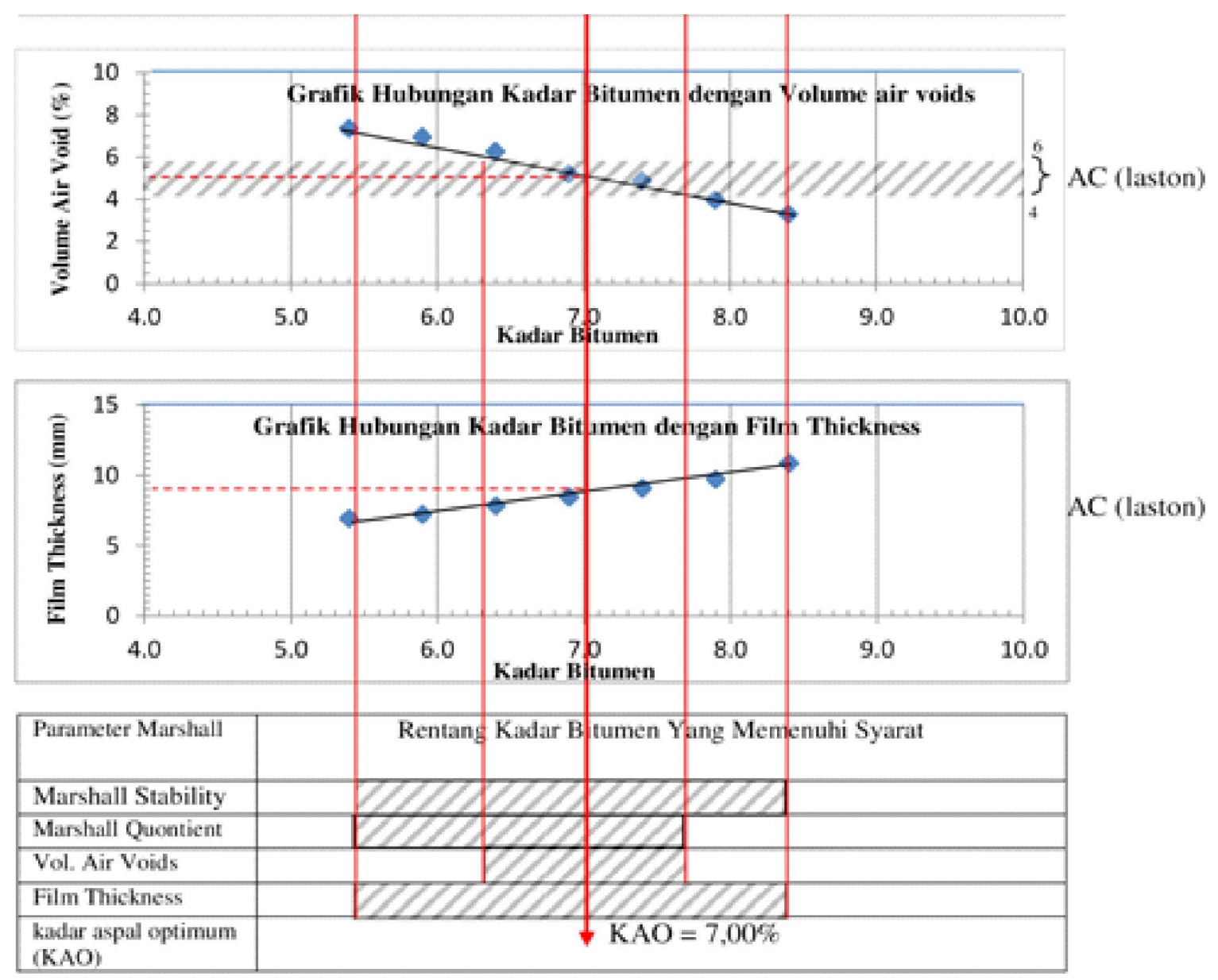

Gambar 2. Grafik Kadar Aspal Optimum

Campuran Laston dengan Limbah Batu Marmer Sebagai Pengganti Sebagian Agregat Kasar

Berdasarkan kadar aspal optimum campuran laston standar $7,00 \%$. Proporsi agregat halus dan bahan pengisi ditetapkan secara konstan yaitu $42,76 \%$ dan $4,72 \%$, sedangkan proporsi batu pecah disesuaikan terhadap proporsi agregat halus, bahan pengisi dan kadar aspal agar volume total campuran 100\%. Dengan demikian komposisi agregat kasar adalah $45,52 \%$. Agregat pasir alam dan abu batu disesuaikan berdasarkan perbandingan analisa saringan yaitu 50:50 (masing-masing adalah $21,38 \%)$. Adapun variasi kadar limbah batu marmer yang dicoba adalah $5 \%, 10 \%, 15 \%, 20 \%, 25 \%$, $30 \%, 35 \%$ dari total proporsi agregat kasar. Penyesuaian proporsi campuran nominal laston dengan limbah batu marmer disajikan pada tabel 9 dan proporsi campuran agregat laston dengan limbah batu marmer ditunjukkan pada tabel 10. Benda uji dibuat berdasarkan perhitungan gradasi agregat campuran laston dengan limbah batu marmer yang dihasilkan dari gradasi agregat kombinasi dan gradasi agregat campuran laston dengan limbah batu marmer (Tabel 11).

Tabel 9. Penyesuaian Proporsi Campuran Nominal Laston Dengan Limbah Batu Marmer

\begin{tabular}{|c|c|c|c|c|c|c|c|c|}
\hline \multirow{3}{*}{ MATERIAL } & \multirow{3}{*}{$\begin{array}{l}\text { Camp. } \\
\text { Nominal } \\
\text { laston } \\
\text { standar }\end{array}$} & \multicolumn{7}{|c|}{ Proporsi Campuran Nominal Laston Dengan limbah batu marmer } \\
\hline & & 1 & 2 & 3 & 4 & 5 & 6 & 7 \\
\hline & & $5 \%$ & $10 \%$ & $15 \%$ & $20 \%$ & $25 \%$ & $30 \%$ & $35 \%$ \\
\hline Batu Pecah & 45,52 & 43,24 & 40,97 & 38,69 & 36,42 & 34,14 & 31,86 & 29,59 \\
\hline Limbah Batu Marmer & 0,00 & 2,28 & 4,55 & 6,83 & 9,10 & 11,38 & 13,66 & 15,93 \\
\hline Abu Batu & 21,38 & 21,38 & 21,38 & 21,38 & 21,38 & 21,38 & 21,38 & 21,38 \\
\hline Pasir Alam & 21,38 & 21,38 & 21,38 & 21,38 & 21,38 & 21,38 & 21,38 & 21,38 \\
\hline Bahan pengisi & 4,72 & 4,72 & 4,72 & 4,72 & 4,72 & 4,72 & 4,72 & 4,72 \\
\hline
\end{tabular}




\begin{tabular}{lcccccccc}
\hline Aspal (A) & 7,00 & 7,00 & 7,00 & 7,00 & 7,00 & 7,00 & 7,00 & 7,00 \\
TOTAL & 100 & 100 & 100 & 100 & 100 & 100 & 100 & 100 \\
\hline
\end{tabular}

Tabel 10. Proporsi Campuran Agregat Laston Dengan Limbah Batu Marmer

\begin{tabular}{lccccccc}
\hline \multicolumn{1}{c}{ MATERIAL } & \multicolumn{7}{c}{ Proporsi Campuran Agregat (\%) } \\
& 1 & 2 & 3 & 4 & 5 & 6 & 7 \\
& $5 \%$ & $10 \%$ & $15 \%$ & $20 \%$ & $25 \%$ & $30 \%$ & $35 \%$ \\
\hline Batu Pecah & 46,50 & 44,05 & 41,60 & 39,16 & 36,71 & 34,26 & 31,82 \\
Limbah Batu Marmer & 2,45 & 4,89 & 7,34 & 9,79 & 12,24 & 14,68 & 17,13 \\
Abu Batu & 22,99 & 22,99 & 22,99 & 22,99 & 22,99 & 22,99 & 22,99 \\
Pasir Alam & 22,99 & 22,99 & 22,99 & 22,99 & 22,99 & 22,99 & 22,99 \\
Bahan Pengisi & 5,08 & 5,08 & 5,08 & 5,08 & 5,08 & 5,08 & 5,08 \\
TOTAL & 100 & 100 & 100 & 100 & 100 & 100 & 100 \\
\hline
\end{tabular}

Hasil pemeriksaan campuran laston dengan limbah batu marmer dengan menggunakan alat Marshall disajikan pada tabel 12. Dan rangkuman

nilai rata-rata karakteristik marshall campuran laston dengan limbah batu marmer disajikan pada tabel 13.

Tabel 11. Gradasi Agregat Kombinasi Dan Luas Total Permukaan Agregat Campuran Laston Dengan Limbah Batu Marmer

\begin{tabular}{|c|c|c|c|c|c|c|c|c|c|c|c|c|c|}
\hline \multirow{2}{*}{$\begin{array}{c}\text { SARING } \\
\text { AN } \\
\text { ASTM }\end{array}$} & \multirow[b]{2}{*}{ A } & \multicolumn{5}{|c|}{ GRADASI AGREGAT } & \multicolumn{2}{|c|}{ GRADASI } & \multicolumn{3}{|c|}{ AGREGAT KOMBINASI } & \multirow[b]{2}{*}{ VII } & \multirow{2}{*}{$\begin{array}{c}\text { FAKT. } \\
\text { PERMU } \\
\text { KAAN } \\
\text { AGRE. }\end{array}$} \\
\hline & & B & $\mathrm{C}$ & $\mathrm{D}$ & $\mathrm{E}$ & I & II & III & IV & $\mathrm{V}$ & VI & & \\
\hline $1 “$ & 100 & 100 & 100 & 100 & 100 & 100 & 100 & 100 & 100 & 100 & 100 & 100 & \multirow{4}{*}{$-1 \times 0.41$} \\
\hline $3 / 4 “$ & 100 & 100 & 100 & 100 & 100 & 100 & 100 & 100 & 100 & 100 & 100 & 100 & \\
\hline $1 / 2 *$ & 43,28 & 61,54 & 100 & 100 & 100 & 72,68 & 73,58 & 73,03 & 74,03 & 74,47 & 74,92 & 75,37 & \\
\hline $3 / 8 “$ & 6,88 & 50,22 & 100 & 100 & 100 & 55,48 & 57,60 & 58,66 & 58,66 & 59,72 & 60,79 & 61,85 & \\
\hline$\# 4$ & 1,86 & 31,00 & 100 & 100 & 100 & 52,68 & 54,10 & 54,82 & 54,82 & 55,53 & 56,24 & 56,96 & $\times 0.41$ \\
\hline \# 8 & 1,40 & 19,18 & 95,58 & 96,92 & 100 & 50,45 & 51,32 & 51,76 & 51,76 & 52,19 & 52,63 & 53,06 & $\times 0.82$ \\
\hline \# 16 & 1,28 & 14,95 & 87,75 & 85,71 & 100 & 45,91 & 46,58 & 46,92 & 46,92 & 47,25 & 47,59 & 47,92 & $\times 1.64$ \\
\hline \# 30 & 1,10 & 12,28 & 75,71 & 77,05 & 100 & 41,01 & 41,55 & 41,83 & 41,83 & 42,10 & 42,37 & 42,65 & $\times 2.87$ \\
\hline \# 50 & 0,87 & 9,32 & 49,68 & 50,34 & 100 & 2870 & 29,12 & 29,32 & 29,32 & 29,53 & 29,74 & 29,94 & $\times 6.14$ \\
\hline \#100 & 0,71 & 3,40 & 21,08 & 25,50 & 100 & 16,20 & 16,33 & 16,39 & 16,39 & 16,46 & 16,53 & 16,59 & $\times 12.29$ \\
\hline \# 200 & 0,52 & 0,75 & 4,35 & 4,29 & 100 & 7,32 & 7,33 & 7,34 & 7,34 & 7,34 & 7,35 & 7,36 & $\times 32.27$ \\
\hline Perban & \multicolumn{5}{|c|}{ a. Agregat Kasar } & 46,50 & 44,05 & 41,60 & 39,16 & 36,71 & 34,26 & 31,82 & \\
\hline Camp. & \multicolumn{5}{|c|}{ b. Limbah Batu Marmer } & 2,45 & 4,89 & 7,34 & 9,79 & 12,24 & 14,68 & 17,13 & \\
\hline Agre. $(\%$ & \multicolumn{5}{|c|}{ c. Abu Batu } & 22,99 & 22,99 & 22,99 & 22,99 & 22,99 & 22,99 & 22,99 & \\
\hline Berat & \multicolumn{5}{|c|}{ d. Pasir } & 22,99 & 22,99 & 22,99 & 22,99 & 22,99 & 22,99 & 22,99 & \\
\hline Tot.agre) & \multicolumn{5}{|c|}{ e. Bahan Pengisi } & 5,08 & 5,08 & 5,08 & 5,08 & 5,08 & 5,08 & 5,08 & \\
\hline \multicolumn{6}{|c|}{ LUAS TOT. PERMUKAAN AGREGAT (M²/Kg) } & 8,50 & 8,95 & 9,01 & 9,06 & 9,11 & 9,17 & 8,81 & \\
\hline
\end{tabular}

Tabel 12. Hasil Pemeriksaan Campuran Laston Dengan Limbah Batu Marmer Menggunakan Alat Marshall

\begin{tabular}{ccccccc}
\hline No. & \multicolumn{6}{c}{ Bacaan Arloji Marshall Test } \\
\cline { 2 - 7 } Benda & \multicolumn{7}{c}{ Stabilitas } & Flow \\
\cline { 2 - 7 } Uji & A & B & C & A & B & C \\
\hline 1. & 15 & 20 & 18 & 395 & 290 & 390 \\
2. & 15 & 12 & 21 & 365 & 325 & 490 \\
3. & 25 & 20 & 14 & 340 & 350 & 340 \\
4. & 22 & 20 & 16 & 450 & 380 & 370 \\
5. & 15 & 19 & 23 & 310 & 290 & 340 \\
6. & 16 & 19 & 21 & 410 & 420 & 480 \\
7. & 28 & 25 & 19 & 660 & 590 & 470 \\
\hline
\end{tabular}


Tabel 13. Nilai Rata-rata Karakteristik Marshall Campuran Aspal Laston Dengan Limbah Batu Marmer

\begin{tabular}{ccccc}
\hline $\begin{array}{c}\text { Kadar Limbah Batu } \\
\text { Marmer }(\%)\end{array}$ & $\begin{array}{c}\text { Marshall Stability } \\
(\mathrm{kg})\end{array}$ & $\begin{array}{c}\text { Marshall Quotient } \\
(\mathrm{kn} / \mathrm{mm})\end{array}$ & $\begin{array}{c}\text { Film } \\
\text { Tchikness }(\mathrm{mm})\end{array}$ & $\begin{array}{c}\text { Volume Air } \\
\text { Void }(\%)\end{array}$ \\
\hline $5,00 \%$ & 978,50 & 2,68 & 9,12 & 5,05 \\
$10,00 \%$ & 912,30 & 2,27 & 8,69 & 4,87 \\
$15,00 \%$ & 1048,80 & 2,99 & 8,66 & 4,59 \\
$20,00 \%$ & 1050,60 & 2,58 & 8,64 & 4,45 \\
$25,00 \%$ & 1042,50 & 3,26 & 8,61 & 4,15 \\
$30,00 \%$ & 1051,71 & 2,36 & 8,59 & 4,01 \\
$35,00 \%$ & 1139,94 & 1,95 & 8,96 & 3,80 \\
\hline
\end{tabular}

Berdasarkan nilai rata-rata karakteristik marshall campuran laston dengan limbah batu marmer (Tabel 13), dibuat grafik hubungan antara kadar limbah batu marmer sebagai absis dengan karakteristik marshall campuran laston dengan limbah batu marmer sebagai ordinat yang divisualisasikan sebagaimana gambar 3. Campuran laston dengan limbah batu marmer sebagai pengganti agregat kasar pada kadar limbah batu marmer 5\%35\% menghasilkan Marshall Stability 978,501139,94 kg, dan Marshall Quotient 68-1,952KN/ mm. Pada kadar limbah batu marmer 5\%-30\% menghasilkan Volume Air Void 5,05-4,01\%, serta pada kadar limbah batu marmer 5-35\% menghasilkan Film Thickness 9,12-8,96 mm. Campuran laston dengan limbah batu marmer sebagai pengganti agregat kasar menghasilkan kadar limbah batu marmer optimum 17,5\%, menghasilkan kualitas campuran : marshall stability $1050 \mathrm{~kg}$, marshall quotient $2,5 \mathrm{KN} / \mathrm{mm}$, volume air void $4,5 \%$ dan film thickness $8,8 \mathrm{~mm}$.

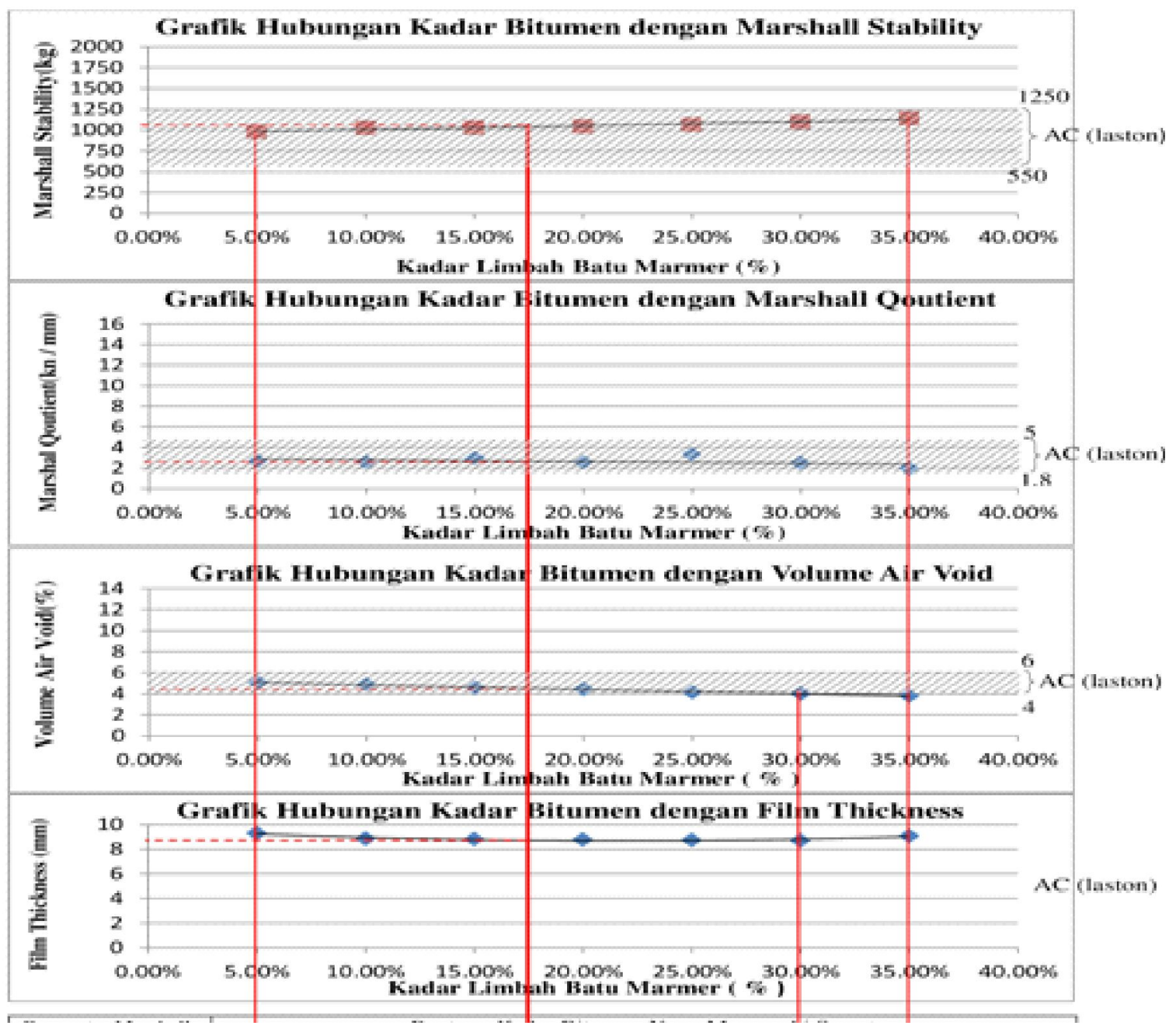




\begin{tabular}{|c|c|c|}
\hline Paramcier Marwhall & Rentung Kuglar Bitumen Tung Memenuli syurat & \\
\hline \multicolumn{3}{|l|}{ Markhaili Stability } \\
\hline \multicolumn{3}{|l|}{ Marahall Qucutient } \\
\hline \multicolumn{3}{|l|}{ Volume Air Voids } \\
\hline \multicolumn{3}{|l|}{ Pilun Thieknews } \\
\hline  & S & \\
\hline
\end{tabular}

Gambar 3. Grafik Kadar Limbah Batu Marmer Optimum

Berdasarkan dari hasil pengujian marshall didapat perubahan kualitas campuran laston standar dengan campuran laston dengan limbah batu marmer sebagai pengganti agregat kasar terhadap nilai Marshall Stability, Marshall Quotient, Volume Air Void dan film thickness.

\section{Marshall Stability}

Nilai marshall stability campuran laston dengan limbah batu marmer sebagai pengganti sebagian agregat kasar pada kadar limbah batu marmer 0\% (standar), sebesar $799 \mathrm{~kg}, 5 \%$ ada kenaikan sampai 978,50 kg sampai penambahan limbah batu marmer $35 \%$ mengalami kenaikan sampai $1139 \mathrm{~kg}$, maka marshall stability campuran laston dengan limbah batu marmer secara umum mengalami kenaikan kualitas campuran.

\section{Marshall Quotient}

Nilai marshall quotient campuran laston dengan limbah batu marmer sebagai pengganti agregat kasar pada kadar limbah batu marmer $0 \%$ (standar), sebesar 2,00 kn/mm, 5\% sebesar 2,68 kn/ $\mathrm{mm}, 10 \%$ sebesar $2,27 \mathrm{kn} / \mathrm{mm}, 15 \%$ sebesar 2,99 $\mathrm{kn} / \mathrm{mm}, 20 \%$ sebesar $2,58 \mathrm{kn} / \mathrm{mm}, 25 \%$ sebesar 3,26 $\mathrm{kn} / \mathrm{mm}, 30 \%$ sebesar $2,36 \mathrm{kn} / \mathrm{mm}$ dan $35 \%$ sebesar $1,95 \mathrm{kn} / \mathrm{mm}$, maka marshall quotient campuran laston dengan limbah batu marmer masuk dalam kategori fluktuatif, tetapi masih memenuhi syarat atau batasbatas yang telah ditentukan.

\section{Volume Air Void}

Untuk nilai volume air void campuran laston dengan limbah batu marmer sebagai pengganti sebagian agregat kasar pada kadar limbah marmer $0 \%$ (standar), sebesar 5,00\%, 5\% ada kenaikan sampai 5,05\%, pada penambahan kadar limbah batu marmer $10 \%$ sampai $35 \%$ mengalami penurunan sampai $4,87 \%, 4,59 \%, 4,45 \%, 4,15 \%, 4,01 \%$ dan
$3,80 \%$, maka volume air void campuran laston dengan limbah batu marmer mengalami penurunan, tetapi masih memenuhi batas-batas persyaratan yang telah di tentukan.

\section{Film Thickness}

Nilai film thickness campuran Laston dengan limbah batu marmer sebagai pengganti sebagian agregat kasar pada kadar limbah batu marmer 0\% (standar), sebesar 9,00 mm, 5\% mengalami kenaikan sampai $9,12 \mathrm{~mm}, 10 \%$ sebesar $8,69 \mathrm{~mm}, 15 \%$ sebesar $8,66 \mathrm{~mm}, 20 \%$ sebesar $8,64 \mathrm{~mm}, 25 \%$ sebesar $8,61 \mathrm{~mm}, 30 \%$ sebesar $8,59 \mathrm{~mm}$ dan $35 \%$ sebesar $8,96 \mathrm{~mm}$, maka film thickness campuran laston dengan limbah batu marmer mengalami fluktuatif.

\section{KESIMPULAN DAN SARAN}

\section{Kesimpulan}

- Dari hasil pengujian Marshall, campuran Laston dengan limbah batu marmer sebagai pengganti agregat kasar, dengan kadar limbah batu marmer mulai 5\% - 35\%, diketahui ada pengaruh kualitas campuran terhadap karakteristik marshall.

- Campuran aspal Laston dengan limbah batu marmer sebagai pengganti agregat kasar, pada kadar limbah batu marmer optimum 17,5\%, menghasilkan kualitas campuran : marshall stability $1050 \mathrm{~kg}$, marshall quotient 2,5 KN/ $\mathrm{mm}$, volume air void $4,5 \%$ dan film thickness $8,8 \mathrm{~mm}$.

\section{Saran}

- Pemanfaatan limbah batu marmer dapat digunakan untuk campuran aspal seperti Latasir, Lataston, ATB dan campuran lainnya. 


\section{DAFTAR PUSTAKA}

Andi SA, 2010, Pemanfaatan Abu Bagasse Sebagai Filler Terhadap Nilai Marshall Test Pada Campuran ATB, Prosiding Simposium XIII Forum Studi Transportasi Antar Perguruan Tinggi, Universitas Katolik Soegijapranata Semarang.

Andi SA, 2011, Pengaruh Bentuk Penggunaan Agregat Kasar Terhadap Nilai Stabilitas Pada Campuran Aspal Beton, Laporan Tidak Dipublikasikan DP2M Universitas Muhammadiyah Malang.

Istikomah, Nurul, (2005), Evaluasi Penggunaan Limbah Pecahan Marmer Tulungagung Sebagai Agregat Halus Pada Campuran Laston, Tugas Akhir Tidak Diterbitkan, Jurusan Teknik Sipil, Fakultas Teknik Universitas Brawijaya Malang.

Sukirman, S, (2003), Beton Aspal campuran Panas, Penerbit Nova, Bandung.

Tjangroe, dkk, (2006), Pecahan Marmer Sebagai pengganti Agregat Kasar Self Compacting concrete (SCC), Jurnal Desain dan Kontruksi, Vol. 5, No.

SNI 03-1737-1989, Pelaksanaan lapis campuran beraspal panas.

SNI 06-2432-1991, Metode pengujian daktilitas bahan-bahan aspal.

SNI 06-2441-1991, Metode pengujian berat jenis aspal padat.

SNI 06-2489-1991, Metode Pengujian Campuran Aspal dengan Alat Marshall.

SNI 03-6723-2002, Spesifikasi bahan pengisi untuk campuran beraspal.

SN.13.6000.03.06, 2012, Angka Kalibrasi Alat Uji Tekan - Marshal Test No. Seri 03.6000.03.06. 